\section{Happy Birthday!}

Marjorie Senechal

This column is a forum for discussion

of mathematical communities

throughout the world, and through all

time. Our definition of "mathematical

community" is the broadest. We

include "schools" of matbematics,

circles of correspondence,

mathematical societies, student

organizations, and informal

communities of cardinality greater

than one. What we say about the

communities is just as unrestricted.

We welcome contributions from

mathematicians of all kinds and in

all places, and also from scientists,

bistorians, anthropologists, and

others.

Please send all submissions to

Marjorie Senechal, Department

of Mathematics, Smith College,

Northampton, MA 01063 USA

e-mail: senechal@minkowski.smith.edu rom its inception as a pampblet

in 1971 and through 30 years as

a magazine The Mathematical Intelligencer bas been a cbronicle, and cbronicler; of the intemational matbematical community. (Indeed, it bas belped to create that community.) But The Mathematical Intelligencer doesn't just bappen-it's the creation of its lively, imaginative, and bardworking editors and the wonderfully resourceful and forbearing Springer staff. And so, for this 30th anniversary issue's "Mathematical Communities" column, I've asked my predecessors and Coeditor-inChief to reflect on their years at the belm.

- Marjorie Senechal

\section{A Conversation with Klaus and Alice Peters, Founders (with Walter Kaufmann-Bühler)}

Mariorie Senechal (MS): So this is the original Matbematical Intelligencer!

Klaus Peters (KP): You've never seen it before?

MS: Never. Our library has all the issues of the magazine, starting with volume 1 , but not these pamphlets. They're prehistory.

Alice Peters (AP): Unfortunately, it has a lot of holes in it

MS: It's typed on a typewriter! How did you get it into this form?

KP: There was a format called an accordion print or fold; our production department at Springer could do it.

AP: We, that is our friend and colleague Walter Kaufmann-Bühler, Klaus, and I, used to do this completely on our own time. Well, being publishers, we don't really think about time as our own time or work time. But we used to do it in the evenings, at our house. We'd open a nice bottle of wine and have a lot of fun and do silly things and come up with crazy ideas of what we might do. ... It was just sort of, oh let's just sit around and talk and then come up with ideas. MS: The first issue, numbered 0 , includes your editorial statement (Fig. 1), an obituary of Heinz Hopf translated from the Neue Zïrcher Zeitung, a review by C. L. Siegel of Constance Reid's Hilbert, reprinted from the Times Literary Supplement, excerpted memories of I. Schur, by A. Brauer, and a list of forthcoming Springer books .

KP: We typed it as we went along.

AP: I typed and he talked and that's how it all came about.

MS: Where did the name, The Mathematical Intelligencer, come from?

KP: Walter, I think. I remember a discussion about whether people would know what it meant. "Intelligencer" means spy, reporter, and is sometimes used in the names of newspapers; today a lot of people have never heard of it. But Walter had a strong sense of history.

AP: We also asked Peter Hilton if he thought it was appropriate, and he thought it was fine.

MS: I think everyone likes it, even if they don't understand it.

KP: Walter was the most low-key, unassuming person you could ever have known. He would never put himself in the center, he was always very modest, but he knew what he wanted. When we discussed something he was always firm in his opinion, but he would never push himself. One day we published a new edition of a book in the "Yellow Series" by the well-known mathematician Arthur Schoenflies. Walter had just joined the editorial department. He had started at Springer as a marketing person because there wasn't an editorial job, but after a few days, we agreed that we'd both do both, I would do some marketing and Walter some of editorial work, and vice versa. When we decided to do the Schoenflies book he said "Oh, that's really nice, you know, I know him". "How do you know him?" "Oh, he's my grandfather."

MS: May I borrow this issue?

AP: Guard it with your life! I don't know if even Springer has another one. When Springer moved to its new offices, they might not have kept them. 